\title{
Impact of Corporate Governance on Corporate Sustainable Growth
}

\author{
Tutun Mukherjee*, Som Sankar Sen** \\ * Department of Commerce, The University of Burdwan, West Bengal, and St. Xavier's University, Kolkata, India \\ **Department of Commerce, The University of Burdwan, West Bengal, India.
}

\begin{tabular}{|c|c|}
\hline ARTICLE INFO & A B S T RACT \\
\hline \multirow[t]{3}{*}{$\begin{array}{l}\text { JEL: G3, G30, G32, G34, G38 } \\
\text { Keywords: } \\
\text { corporate sustainable growth, } \\
\text { corporate governance, } \\
\text { longitudinal data analysis, } \\
\text { control variable, India } \\
\text { Kata Kunci: } \\
\text { pertumbuhan berkelanjutan } \\
\text { perusahaan, } \\
\text { tata kelola perusahaan, } \\
\text { analisis data longitudinal, } \\
\text { variabel kontrol, } \\
\text { India }\end{array}$} & $\begin{array}{l}\text { It is believed that good corporate governance practices assist } \\
\text { significantly in uplifting corporate performance, and brings in business } \\
\text { success and sustainability. This study aims to shed light on the impact } \\
\text { of corporate governance practices on corporate sustainable growth in } \\
\text { India. A sample size of leading } 139 \text { non-financial companies listed in } \\
\text { NSE for five years has been used in this study. Using longitudinal data } \\
\text { analysis, the findings of the study suggest that Board Size (BS) and the } \\
\text { Board Independence (B-IND) exercise strong influence in explaining } \\
\text { the Corporate Sustainable Growth in India after controlling the effect } \\
\text { of Leverage (LEV). }\end{array}$ \\
\hline & SARI PATI \\
\hline & $\begin{array}{l}\text { Diyakini bahwa praktik tata kelola perusahaan yang baik sangat } \\
\text { membantu dalam meningkatkan kinerja perusahaan, dan membawa } \\
\text { keberhasilan dan keberlanjutan bisnis. Penelitian ini bertujuan } \\
\text { untuk menjelaskan dampak praktik tata kelola perusahaan pada } \\
\text { pertumbuhan berkelanjutan perusahaan di India. Sebanyak } 139 \\
\text { sampel perusahaan non-keuangan terkemuka yang terdaftar } \\
\text { selama lima tahun di NSE telah digunakan dalam penelitian ini. } \\
\text { Menggunakan analisis data longitudinal, temuan penelitian ini } \\
\text { menunjukkan bahwa Ukuran Dewan atau jumlah Dewan Direksi (BS) } \\
\text { dan Dewan Independen (B-IND) memiliki pengaruh yang kuat dalam } \\
\text { menjelaskan Pertumbuhan Berkelanjutan Perusahaan di India setelah } \\
\text { mengendalikan efek Leverage (LEV). }\end{array}$ \\
\hline
\end{tabular}

(C) 2019 IRJBS, All rights reserved.

Corresponding author: 


\section{INTRODUCTION}

'Corporate governance' has turned out to be one of the buzzwords in the language of global business. The global financial catastrophe that swept the financial markets and economies around the world, causing bankruptcies and resulting economic recession has pushed the concept of corporate governance into the limelight (Pintea \& Fulop, 2014). The concept of corporate governance "encompasses policies, processes, and people, designed to govern the companies towards sustainable value generation." It is believed that corporate governance in its practical application is an important key that unlocks the true value of a business regardless of the firm size (Bates, 2013). The practice of good governance in a company mitigates risk, improves performance, opens the way to efficient financial markets, and establishes an attractive investment climate, showing transparency and social responsibility (Pintea \& Fulop, 2014).

On the other hand, sustainable growth is becoming more and more important for all the companies, across the globe. Strategically, 'value-creation' is the ultimate mission of all what we do. However, in today's global competitive battles, a mere maximizing growth may assist the company to accomplish its short-term goals but not the longrun objective what they seek to i.e., the 'valuecreation' (Ramezani et al., 2001). Empirical shreds of evidence too, suggests that value creation maximizes around sustainable growth rate of an organization and decreases sharply, once actual growth exceeds sustainable growth rate (Ataünal et al., 2016). Thus, realizing the empirical fact, many companies have been pushing hard for attaining sustainable growth and integrating the same into their long-term strategic plan. Despite the emerging orientation of corporate growth, the legitimate question of how to achieve sustainable growth remains a profound mystery for corporate managers.

Sakai \& Asaoka (2003) believe establishing an adequate and effective corporate governance system is the pre-requisite to enable sustainable growth of the firms. Pintea \& Fulop (2014) support the view and claimed good corporate governance practices play a crucial role to assure corporate sustainable growth, in the present context of globalization. Empirical shreds of evidence as well, suggests that corporate governance practices exercise strong influence in explaining the corporate sustainable growth (Li et al. 2015).

In this comprehensive framework, this study aims to shed light on the impact of corporate governance practices on corporate sustainable growth in India. In doing so, this study adds several novelties to the existing literature. First, this study provides evidence of the impact of corporate governance practices on corporate sustainable growth in India for the first time. Second, the present study considers a sample of top 139 NSE listed non-financial companies with the intent to capture the comprehensive view of best blue-chip companies along with the mid-cap companies in India. Third, instead of focusing on a single metric framework (i.e., an index) with the intent to capture the impact of the different facets of corporate governance practices on corporate sustainable growth more precisely, the present study utilizes a range of corporate governance measures (including Board Size, Proportion of Women Directors on the Board, CEO's Duality, Boards Education, Board Independence, and Presence of Family Affiliation on the Board). Fourth, the present study can help the policymakers in framing effective governance policies for the Indian companies in light of corporate sustainable growth. Lastly, in today's global competitive battles managing, corporate growth is a big confrontation for corporate managers. To such a degree, this study can help corporate managers in managing the firm's growth and its policies effectively.

In accordance with the core objective, the rest of this paper is organized as follows: Second section deals with Literature Review and Hypothesis development. The subsequent section delineates the Research Methods. Then, Results and Discussions, 
and Managerial Implications are presented, and the last section concludes the paper.

\section{LITERATURE REVIEW AND HYPOTHESIS DEVELOPMENT}

Corporate Governance and its theoretical perspective

It is difficult to point out one universal definition of corporate governance, as it is a complex, multiparadigmatic and highly interdisciplinary subject (Klepczarek, 2017). However, in common jargon, "corporate governance represents the system by which corporations are managed and controlled" (Van Horne \& Wachowicz, 2015, pp. 8). It defines the roles of the board of directors in managing the company and maintaining the relationship with the company's shareholders (Pass, 2004). According to Shleifer \& Vishny (1997), "corporate governance is the process through which suppliers of finance to corporations gain assurance of return on their investment." While Blair (1995) defines corporate governance as "a whole set of legal, cultural and institutional arrangements that determine what public corporations can do, who controls them, how this control is exercised and how the risks and return from the activities they undertake are allocated."

Regarding the theoretical perspective of corporate governance, several theories have been used over time to explore the relationship between corporate governance practices and firms performance. Amongst them, the four widely used theories viz. Agency theory, Stewardship theory, Stakeholders theory, and Resource Dependence theory are discussed as under:

\section{Agency Theory}

Agency theory is considered as one of the dominant theoretical perspectives in the literature on corporate governance (Daily et al., 2003). The key tenet of this theory is the separation of ownership and control (Pandey, 2015, pp. 849). Agency theory discusses situations, in which principals delegate their authority of control and decision-making for particular task to the agents (Eisenhardt, 1989; Ross, 1973) and given the chance, agents in most of the cases behave in a self-interested manner, behaviour that may conflict with the principal's interest (Eisenhardt, 1989; Jensen \& Meckling, 1976). As such, principals enact structural mechanisms that keep an eye on the agent to curb opportunistic behaviour and better align the parties' interest (Madison, 2014; Eisenhardt, 1989; Fama \& Jensen, 1983).

In sum, this theory specifies mechanisms which reduces agency loss (Eisenhardt, 1989) and suggests that agency problems are created, and agency costs are incurred to alleviate these problems (Jensen \& Meckling, 1976).

\section{Stewardship Theory}

The stewardship theory presents a divergent perspective than the agency theory, especially in terms of motivation and control issues of businesses. The key tenet of this theory is trust (Keay, 2017; Kluvers \& Tippet, 2011; Hernandez, 2007). Stewardship theory views manager as stewards (Pandey, 2015, pp. 849) and presumes that they will behave as trustworthy stewards of the organization and focus on the collective well-being of the constituents in the firm regardless of the managers' self-interests (Wesley, 2010; Donaldson \& Davis, 1991).

Putting things together, this theory emphasizes on cooperation and collaboration, and assumes that the manager will act for the collective interest to maximize the value of the firm.

\section{Stakeholder Theory}

The stakeholder theory is merely an extension of the agency view (Amer, 2016). This theory assumes that the "companies and society are independent and therefore the corporation serves a broader social purpose than its responsibilities to shareholders" (Keil \& Nicholson, 2003a). To be more specific, the stakeholder theory is principally based on the premises that a firm's board of directors should be 
working in the best interests of all its stakeholders, rather than only the shareholders. "Stakeholder represents any group or individual who can affect or is affected by the achievement of the organization's objectives" (Freeman, 1984). This group includes - investors, managers, employees, customers, business partners, local communities, civil society and the natural environment (Wheeler \& Sillanpaa, 1997). Freeman et al., (2004) suggest that corporate managers should try to create as much as value for stakeholders as possible by resolving existing conflicts among them so that the stakeholders do not exit the deal.

In sum, this theory aims to ensure that the interests of the stakeholders are aligned with that of shareholders (Pandey, 2015, pp. 850).

\section{Resource Dependence Theory}

The 'Resource Dependence Theory' is developed by the American theorists, Jeffrey Pferrer and Gerald Salancik, in the year 1978, in which the board of directors is considered as a resource that can, not only supplant its need for other resources, but also influence the environment in its favour, and thereby improve firm performance (Bathula, 2008). The underlying proposition of this theory represents the need for environmental linkages between the firm and outside directors (Yusoff \& Alhaji, 2012). Accordingly, the board of directors is considered as a link between the firm and the key resources (i.e., information, skills, access to constituents, and legitimacy) that a firm needs from the external environment for better performance and growth.

Putting things together, this theory perceives "the board members, with their knowledge, skills, talents, and professional experience, may be helpful in providing advice and counselling to management in case of limited or lack of inside knowledge. In addition, they could also provide the firm with access to scarce resources by providing the firm with access to their networks" (Sarens \& Merendino, 2016).

\section{Corporate Sustainable Growth}

The words "Sustainable Growth" do not have a rigid definition. It holds different meanings to different people and groups. However, from a financial perspective, sustainable growth implies "an affordable growth that can be sustained profitably for future benefits." The concept of corporate sustainable growth became popularized by Higgins in the year 1977, where he first proposed the use of sustainable growth rate model in explaining the practical limit for growing firms. The model of sustainable growth rate explicates "whether or not the firm's proposed growth plan can be funded within its existing financial parameters" (Firer, 1995). More specifically, sustainable growth rate seeks to explain "the utmost annualized growths in the percentage of sales a firm can afford without issuing any further (i.e. new) equity or, altering its financial policies."

\section{Board Size and Corporate Sustainable Growth}

Board size reflects the number of directors representing the board. It is considered to be one of the crucial factors to decide the efficiency and decision-making process of a firm (Nazar and Rahim, 2015). However, identifying an appropriate board size has remained a matter of continuing debates (Hermalin \& Weisbach, 2003; Yermack, 1996; Jensen, 1993). Jensen (1993) believes as boards become larger, they become less effective and are easier for the CEO to exert his or her control. In addition, over-crowded boards are less cohesive (Lipton and Lorsch, 1992), and more difficult to coordinate (Forbes and Milliken, 1999), which possibly can deteriorate the firm's performance. A numerous number of prior studies (Orozco et al., 2018; Zabri et al., 2016; Ali, 2016; Azeez, 2015; Nazar and Rahim, 2015; Canh et al., 2014; Arosa et al., 2013; Jensen, 2012; Gill \& Mathur, 2011; Guest, 2009; Mashayekhi \& Bazaz, 2008; Singh \& Davidson, 2003; Hermalin \& Weisbach, 2003; Vafeas, 1999; Eisenberg et al., 1998; Yermack, 1996; Jensen, 1993; Lipton \& Lorsch, 1992) offers evidence that smaller and the limited size boards are more efficient and delivers a superior corporate performance. 
There are, however, strong contradicting views in the literature, regarding this. The contrary school of thought believes larger boards are more efficient and tends to deliver superior corporate performance. It is believed that larger boards have directors from diverse backgrounds possessing different sets of talent, skill, and professional experience, which improves boards planning and decision-making practice and thereby enhance firms' performance. Prior researches by Herdjiono \& Sari (2017), Arora \& Sharma (2016), Kalsie \& Shrivastav (2016), Oludele et al. (2016), Fauzi \& Locke (2012), Coles et al. (2008), Pearce \& Zahra (1992) offers evidence that there exists a significant positive relationship between board size and the corporate performance. Thus, we hypothesize:

H1: Board Size (BS) have a positive impact on attaining corporate sustainable growth.

\section{Proportion of Women Directors on the Board and Corporate Sustainable Growth}

The presence of women director on the corporate boards has been increasingly recognized as an obligatory element of good corporate governance practices. It is asserted that women directors are more diligent as compared to the male ones in terms of attending the board meeting, monitoring performance, and others (Appiadjei et al., 2017; Khan et al., 2017; Erhardt et al., 2003; Carter et al., 2003). In addition, women's are more cautious, less overconfident, and are innately more riskaverse than men's. These traits intensify the board's decision-making process, the monitoring practice, and the performance. On the other hand, Daunfeldt \& Rudholm (2012) believes that firms with a diverse board likely to incur higher costs as a result of collective decision-making and thereby can deteriorate the firm's performance. Nevertheless, a numerous number of prior studies (Carter et al., 2003; Erhardt et al., 2003; Campbell and MinguezVera, 2007; Srinidhi et al., 2011; Mahadeo et al., 2012; Fan, 2012; Johl, Kaur, and Cooper, 2015; Christiansen et al., 2016; Lee-Kuen et al., 2017; Appiadjei et al., 2017; Sánchez, 2017) have confirmed that the firm's performance gets better with an increase in the proportion of women directors on corporate boards. Thus, we hypothesize:

H2: Proportion of Women Directors on the Board (BS) have a positive impact on attaining corporate sustainable growth.

\section{CEO's Duality and Corporate Sustainable Growth}

CEO's duality is considered to be an important mechanism of board control structure (Bathula, 2008). It is argued when a single individual plays the role of a chairman and the CEO simultaneously, a conflict of interest and higher agency costs arises (Ehikioya, 2009). In addition, such a centralized leadership authority may lead to management's domination of the board, which results in poor performance (Jensen \& Meckling, 1976; Fama \& Jensen, 1983). The prior empirical evidences (Wanjiru, 2013; Azeez, 2015) also support the same and confirms that a separation of the aforementioned two positions proves beneficial in uplifting a firm's performance. Thus, we hypothesize:

H3: CEO's Duality (DUALITY) have a negative impact on attaining corporate sustainable growth.

\section{Board's Education and Corporate Sustainable Growth}

"Education is the most powerful weapon which you can use to change the world" - Nelson Mandela

Business organizations formed and managed by educated managers tend to perform better than those managed by uneducated managers (Akpan and Amran, 2014). The presence of more qualified directors on the board enriches board's knowledge base, the skill and, the technical base. These enrichments enrich board's decision-making process, and finally, the firm's performance. The studies of Bathula (2008); Ujunwa (2012); and Ali (2016) have confirmed that the firms equipped 
with highly qualified directors on the board tend to perform better. Ljungquist (2007) believes that board members with higher qualifications likely to benefit the firms through a mix of competencies and capabilities, which helps in creating diverse perspectives to decision-making. Thus, we hypothesize:

H4: Boards Education have a positive impact on attaining corporate sustainable growth.

\section{Board Independence and Corporate Sustainable Growth}

Independent directors are entrusted with the responsibility of protecting shareholders interest through impartial decision-making and vigilant monitoring of the governance process. They bring in more skills and knowledge to the company (Kamardin, 2011), and their presence on the board gives greater weight to board`s deliberations and judgment (Heravia et al., 2011). It is widely acknowledged that the ideal board should have a large proportion of outside directors as they bring in a balance of power into the 'upper echelons' of organizations (Hambrick and Mason, 1984). Prior empirical evidence (Laing and Li, 1999; Bebchuk and Weisbach, 2010; Rouf, 2012; Khan and Awan, 2012; Chen, 2015; Liu et al., 2015; Sarpong-Danquah et al., 2018) suggests that the firm's having higher board independence likely to perform better. In sum, independent directors play an imperative role in protecting the shareholder interest (Byrd \& Hickman, 1992). Their effective monitoring reduces agency costs and boosts company performance (Fama, 1980). Thus, we hypothesize:

H5: Board Independence (B-IND) have a positive impact on attaining corporate sustainable growth.

Presence of Family Affiliation on the Board and Corporate Sustainable Growth

Strong family involvement on the board may blur the dissection between a family perspective and its responsibility to other shareholders produced on account of nepotism (Lansberg et al., 1988; Burkart et al., 2003; Pérez-González, 2006) and asymmetric altruism (Schulze et al., 2001). In addition, large family shareholders may use their controlling position in the firm to extract private benefits at the expense of the small shareholders which may have an adverse effect on the firm's performance (Villalonga and Amit, 2006). Thus, we hypothesize:

H6: Presence of Family Affiliation on the Board (P-FAMA) have a negative impact on attaining corporate sustainable growth.

\section{METHODS}

\section{Database}

Primarily, a sample of top 200 NSE listed companies has been drawn out of the target population based on their market capitalization. The above selection has been considered in an anticipation of capturing the comprehensive view of best blue-chip companies along with the mid-cap companies in India. Of the selected sample, 139 non-financial companies have been considered as an ultimate sample size on the basis of purposive sampling. Banks and other financial companies, due to their divergent nature of the operation and capital structure, have been left out of the ultimate sample size. Additionally, a few non-financial companies, due to unavailability of data or of different financial years, failed to be the part of the ultimate sample size. The required financial and corporate governance data of the selected companies have been collected exclusively from Capitaline Database over a time period of five years, i.e., from 2011-12 to 2015-16. The selection of the time period as stated has been considered with an intent to evade the effects of 2008-09 global financial crisis. The present study has been conducted based on the consistently arranged data as per financial years.

\section{Research Variables}

1. Dependent Variable - Corporate Sustainable Growth is the dependent variable in the present study. There are number of ways through which one can quantify corporate sustainable growth. 
However, amongst those, Sustainable Growth Rate (SGR) models of Van Horne and Higgins are universally accepted and used in the prior studies (Mukherjee \& Sen, 2018; Xu \& Wang, 2018; Pandit \& Tejani, 2011). In this study, Van Horne's SGR model has been used as there is no significant difference between these two models (Fonseka, Ramos, and Tian, 2012).

Sustainable Growth Rate (SGR) =

$$
\frac{b\left(\frac{N p}{E q}\right)}{1-\left[b\left(\frac{N p}{E q}\right)\right]} \text { [Van Horne \& Wachowicz, 2015, pp.192] }
$$

or,

$$
=\frac{R O E \times b}{1-(\operatorname{ROE} \times \mathrm{b})} \text { [Ross et al., 2012, pp.104-106] }
$$

Where,

ROE (Return on Equity) =

$$
\frac{\text { Net Profit }}{\text { Total Equity }}
$$

$\mathrm{b}($ Retention Ratio $)=$

\section{PAT - Current Year Dividend}

PAT

2. Independent Variables - Corporate governance represents a multi-dimensional concept. Finance literature reveals that there different ways through which one can enumerate the corporate governance practices. In the present study, with the intent to capture the impact of corporate governance practices on corporate sustainable growth more precisely, a range of corporate governance measures has been considered as independent variables instead of focusing on a single metric framework (i.e., an index). To be more specific, a catalogue of six variables has been taken into consideration, where each of them represents a separate facet of corporate governance practices. First, Board Size (BS), as measured by taking a natural log of total number of directors on the board at period $t$; Second, Proportion of Women Directors on the Board (P-WOM), as measured by number of women directors on the board at period $t$ to Total number of directors on the board at period $t$; Third, CEO's Duality (DUALITY), as measured by using dummy '0' and ' 1 ' i.e., Coded ' 1 ', if Board's Chairman acting as a CEO/Managing Director simultaneously and Coded '0', otherwise; Fourth, Boards Education (B-EDU), as measured by using dummy ' 0 ' and ' 1 ' i.e., Coded ' 1 ', if majority (i.e. more than 50\%) of the directors on the board possessed Master Degree or any Professional Degree, or, any other equivalent degree and Coded '0', otherwise; Fifth, Board Independence (B-IND), as measured by Number of independent directors on the board at period $t$ to Total number of directors on the board at period t; Lastly, Presence of Family Affiliation on the Board (P-FAMA), as measured by using dummy ' 0 ' and ' 1 ' i.e., Coded ' 1 ', if more than one family member on the Board during period $t$ and Coded ' 0 ', otherwise.

3. Control Variable - In the present study, Leverage (LEV), as measured by debt to equity ratio, is considered as control variable. The selection of the said control variable is in line with the previous studies conducted by Mukherjee \& Sen, (2018), Xu \& Wang (2018).

\section{Research Method}

Two regression models have been used in the present study. Model 1 represents the fundamental model, which examines the impact of corporate governance practices viz. Board Size (BS), Proportion of Women Directors on the Board (P-WOM), CEO's Duality (DUALITY), Boards Education (B-EDU), 
Table 1. Summary of the Research Variables and their Proxies

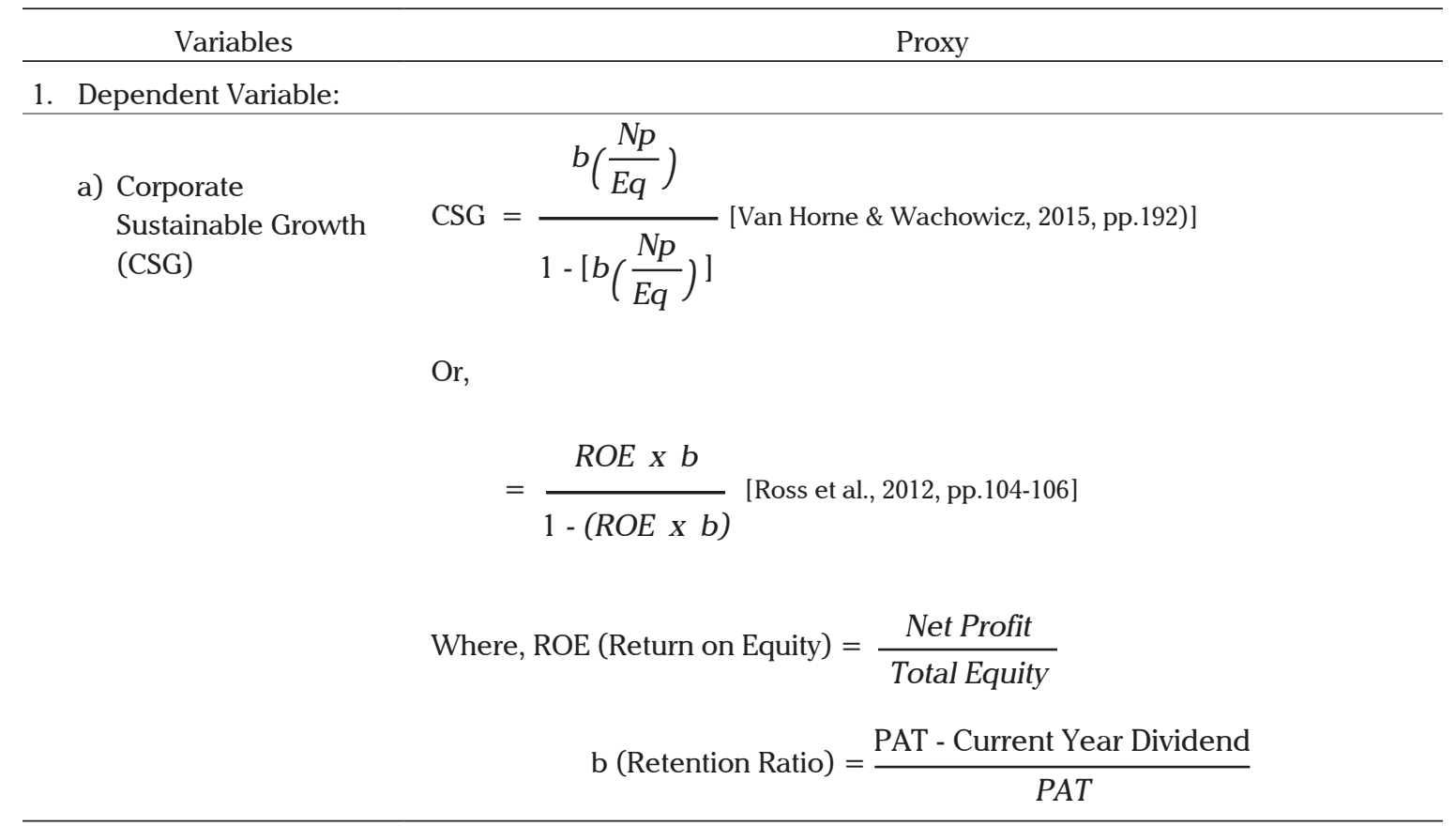

2. Independent Variables:

a) Board Size (BS) $\quad$ BS $=$ Natural log of total number of directors on the board at period $t$

[Azeez, 2015; Che and Langli, 2015; Arosa et al., 2013; Jackling \& Johl, 2009; De Andrés et al., 2005; Anderson \& Reeb, 2003]

b) Proportion of Women Directors on the Board (P-WOM)

c) CEO's Duality (DUALITY)

d) Boards Education (B-EDU)

e) Board Independence (B-IND)

f) Presence of Family Affiliation on the Board (P-FAMA)
$\mathrm{P}-\mathrm{WOM}=\frac{\text { Number of woman directors on the board period } t}{\text { Total number of directors on the board at period } t}$

[Akpan \& Arman, 2014; Ahern and Dittmar, 2012; Yasser, 2012; Nielsen \& Huse, 2010; Adams and Ferreira, 2009]

DUALITY = Coded ' 1 ', if Board's Chairman acting as a CEO/Managing Director simultaneously and Coded '0', otherwise

[Berardino, 2016; Cabrera-Suárez \& Martín-Santana, 2015; Liu et al., 2015; Azeez, 2015; Arosa et al., 2013]

B-EDU $=$ Coded ' 1 ', if majority (i.e. more than 50\%) of the directors on the board possessed Master Degree or any Professional Degree or any other equivalent degree and Coded ' 0 ', otherwise

B-IND $=\frac{\text { Number of independent directors on the board during period } t}{\text { Total number of directors on the board during period } t}$

[Liu et al., 2015; Akpan \& Arman, 2014]

P-FAMA $=$ Coded ' 1 ', if two or more family members on the Board during period $t$ with same last name and Coded ' 0 ', otherwise [Rutherford et al., 2006; Schulze et al., 2001]

3. Control Variable:
a) Leverage (LEV)
$\mathrm{LEV}=\frac{\text { Long } t \text { erm debt }}{\text { Total Equity }}$

[Mukherjee \& Sen, 2018;]

Source: Author's own tabulation

Board Independence (B-IND), and Presence

of Family Affiliation on the Board (P-FAMA) on 
corporate sustainable growth after controlling the profound effect of Leverage (LEV). Model 2 represents the model for robustness test, which examines the impact of corporate governance practices viz. Board Size (BS), Proportion of Women Directors on the Board (P-WOM), CEO's Duality (DUALITY), Boards Education (B-EDU), Board Independence (B-IND), and Presence of Family Affiliation on the Board (P-FAMA) on DEVIATION after controlling the profound effect of Leverage (LEV).

To check the robustness of the basic results, we legitimately consider Deviation (DEV), as measured by corporate actual growth rate minus corporate sustainable growth rate, to represent the alternative measure of corporate sustainable growth and the underlying model as developed is re-estimated. The selection of this alternative measure of corporate sustainable growth is in line with the previous researches conducted by Mukherjee \& Sen (2018), Li et al. (2015), and Amouzesh et al. (2011). The Deviation (DEV) indicates how close or far the firm is to attain sustainable growth. To be more specific, the lesser the deviation, the closer the firm is to attain sustainable growth and vice-versa.

The models are represented as follows:

$\mathrm{CSG}_{i t}=\beta_{1}+\beta_{2} \mathrm{BS}_{i t}+\beta_{3} P W O M_{i t}+$

$\beta_{4}$ DUALITY $_{i t}+\beta_{5} \mathrm{BEDU}_{i t}+\beta_{6} \mathrm{BIND}_{i t}+$

$\beta_{7} P F A M A_{i t}+\beta_{8} L E V_{i t}+\mu_{i t}$

$\mathrm{DEV}_{i t}=\beta_{1}+\beta_{2} \mathrm{BS}_{i t}+\beta_{3} P W O M_{i t}+$

$\beta_{4}$ DUALITY $_{i t}+\beta_{5} \mathrm{BEDU}_{i t}+\beta_{6} \mathrm{BIND}_{i t}+$

$\beta_{7} P F A M A_{i t}+\beta_{8} L E V_{i t}+\mu_{i t}$

Where i (i.e. company) $=1,2,3,4,5 \ldots \ldots 139$ and $\mathrm{t}$ (i.e. time) $=1,2,3,4,5$.

This study consists of 139 companies, and the period is 5 years. Since this study has the characteristic of both cross-sectional and time-series, longitudinal / panel data analysis has to be employed. For the empirical analysis, three options are available: (i) Pooled OLS model; (ii) The fixed effects least squares dummy variable (LSDV) model; (iii) The random effects model (REM).

Now, to select the appropriate model from the above, the following steps have been considered:

Step 1: Selection between Model (i) and Model (iii): Breusch Pagan Test LM Test

The null hypothesis in the Breusch Pagan Test LM Test represents, the variance across entities is Zero. This highlights that there are no random/ panel effects. Now, if the computed value of LM is insignificant, then $H_{0}$ will be accepted, and the pooled OLS regression model should be applied. But if the computed value of LM is significant, then $H_{0}$ will be rejected, and there will be random effects.

Step 2: Selection of fixed effects or random effects: Hausman Test

To decide between fixed or random effects, we have to run a Hausman Test, where, as the null hypothesis represents, there are no fixed effects. Now, if the $\mathrm{H}$ statistics is significant, then $H_{0}$ is rejected, and fixed effect model is retained and vice-versa.

\section{RESULTS AND DISCUSSION}

Table 2 presents descriptive statistics of the selected variables employed in this study. The mean value of CSG is 0.096, which suggests that on an average, the Indian companies have a low sustainable growth capability. The Board Size (BS) ranges from a minimum of 1.386 to a maximum of 3.045 with a mean value of 2.289 , which signifies that on an average, the Indian companies uphold a larger board size. The statistics for P-WOM indicates that within the Indian corporate boards approximately one-tenth represents the women directors. Regarding the CEO's Duality, the statistics suggest that approximately $37 \%$ of the leading companies in India display an incidence of CEO's duality on the board. The statistics for B-EDU indicates that approximately $86 \%$ of Indian companies consist 
Tabel 2. Descriptive Statistics

\begin{tabular}{cccccc}
\hline Variable & Observations & Minimum & Maximum & Mean & Std. Dev. \\
\hline CSG & 695 & -12.852 & 2.269 & 0.096 & 0.574 \\
BS & 695 & 1.386 & 3.045 & 2.289 & 0.299 \\
P-WOM & 695 & 0.000 & 0.375 & 0.105 & 0.078 \\
DUALITY & 695 & 0.000 & 1.000 & 0.374 & 0.484 \\
B-EDU & 695 & 0.000 & 1.000 & 0.859 & 0.348 \\
B-IND & 695 & 0.000 & 1.000 & 0.569 & 0.252 \\
P-FAMA & 695 & 0.000 & 1.000 & 0.540 & 0.499 \\
LEV & 695 & -24.318 & 79.973 & 0.515 & 3.393 \\
\hline
\end{tabular}

Source: Author's own tabulation using XL STAT software

of well-educated boards. As regards Presence of Family Affiliation on the Board (P-FAMA), the statistics suggests that approximately $54 \%$ of the leading companies in India demonstrate a presence of family affiliation on the board. While the statistics for LEV (i.e. mean value of 0.515 ) indicates that the Indian companies upholds a low-geared capital structure.

Table 3 presents Pearson's correlation analysis, which highlights the relationship between the dependent variable and explanatory variables employed in this study. The correlation shows that CSG is positively correlated with BS and P-WOM. However, CSG is negatively associated with CEO'S DUALITY, B-EDU, B-IND, P-FAMA, and LEV. Additionally, the result demonstrates that the correlation amongst all the explanatory variables is minimal i.e. below 0.80 . This offer evidence that no multi-co linearity problem exists amongst the explanatory variables employed in the present study.

Table 4 presents the results of Breusch and Pagan Lagrangian multiplier test (BP test) for the underlying model (i.e., for Model 1). This test assists researchers to determine which model amongst the Pooled OLS and REM represents the best-fitted model for the models as developed in the study. The result shows that the LM statistic is 2.55 and is significant at $5 \%$ level. Accordingly, $H_{0}$ is rejected, and the result of REM (as shown in Table 6) could be accepted for the underlying model as developed. However, there is a need to run FEM and conduct supplementary tests.

Tabel 3. Pearson Correlation Matrix

\begin{tabular}{ccccccccc}
\hline & BS & P-WOM & DUALITY & B-EDU & B-IND & FAM-A & LEV & CSG \\
\hline BS & 1 & & & & & & & \\
P-WOM & -0.005 & 1 & & & & & & \\
DUALITY & 0.071 & -0.047 & 1 & & & & & \\
B-EDU & 0.146 & 0.021 & 0.117 & 1 & & & & \\
B-IND & -0.062 & 0.131 & -0.356 & 0.041 & 1 & & & \\
P-FAMA & 0.157 & 0.080 & 0.016 & -0.175 & 0.221 & 1 & & \\
LEV & 0.028 & 0.092 & 0.076 & 0.024 & 0.010 & 0.088 & 1 \\
CSG & 0.105 & 0.040 & -0.041 & -0.008 & -0.047 & 0.079 & -0.027 & 1 \\
\hline
\end{tabular}

Source: Author's own tabulation using XL STAT software 
Tabel 4. Breusch and Pagan Lagrangian multiplier test for random effects (for Model 1)

\begin{tabular}{lcc}
\hline & Var & sd $=$ sqrt(Var) \\
CSG & 0.330 & 0.574 \\
$\mathrm{e}$ & 0.309 & 0.556 \\
$\mathrm{u}$ & 0.017 & 0.132 \\
chibar2(01) & & $2.55^{* *}$ \\
\hline
\end{tabular}

Source: Author's own tabulation using XL STAT software Notes: $\mathrm{p}<0.05^{* *}, \mathrm{p}<0.01^{*}$

Table 5 presents the result of Hausman Test for the underlying model (i.e., for Model 1). This test assists researchers to determine whether to keep FEM or REM as a preferred model for the models as developed in the study. The result demonstrates chi2(4) is 2.78 and is insignificant. Accordingly, we failed to reject $H_{0}$, and the result of the Random Effect Model (as shown in Table 6) is to be considered a good fit for the underlying model as developed.

Table 6 presents the regression results for the underlying model (i.e., for Model 1). The first explanatory variable, Board Size (BS), demonstrates a significant positive influence on corporate sustainable growth ( $\beta=0.179 ; z=2.222)$. It implies that the firms having a larger board size are more competent to attain sustainable growth. This result is consistent with the resource dependence theory and findings of Herdjiono \& Sari (2017), Arora \& Sharma (2016), Kalsie \& Shrivastav (2016), Oludele et al. (2016), Fauzi \& Locke (2012), Coles et al. (2008), and Pearce \& Zahra (1992) yet contradicts the research by $\mathrm{Li}$ et al. (2015) that observed a significant negative association between board size and corporate sustainable growth. The logical reasoning behind this phenomenon is that larger board size brings a comprehensive range of expertise, knowledge, and experience in diverse fields, thereby, provides an improved corporate governance framework through sound planning; productive decision-making; and superior board monitoring. On the other hand, Proportion of Women Directors on the board (P-WOM) proven not to be significantly influential over corporate sustainable growth. This result indicates that

Tabel 5. Hausman Test (for Model 1)

\begin{tabular}{ccccc}
\hline & $\begin{array}{c}\text { (b) } \\
\text { fe }\end{array}$ & $\begin{array}{c}\text { (B) } \\
\text { re }\end{array}$ & $\begin{array}{c}\text { (b-B) } \\
\text { Difference }\end{array}$ & $\begin{array}{c}\text { sqrt(diag(V_b-V_B)) } \\
\text { S.E }\end{array}$ \\
\hline BS & 0.293 & 0.179 & 0.114 & 0.162 \\
P-WOM & 0.472 & 0.352 & 0.120 & 0.268 \\
DUALITY & 0.019 & -0.089 & 0.108 & 0.134 \\
B-EDU & 0.031 & 0.010 & 0.021 & 0.111 \\
B-IND & -0.249 & -0.215 & -0.034 & 0.145 \\
P-FAMA & -0.138 & 0.097 & -0.235 & 0.189 \\
LEV & -0.007 & -0.006 & -0.001 & 0.004 \\
chi2(4) & & \multicolumn{2}{c}{2.78} & \\
\hline
\end{tabular}

Source: Author's own tabulation using STATA software Notes: $\mathrm{p}<0.05^{* *}, \mathrm{p}<0.01 *$ 
board gender diversity provides no linkage with the corporate sustainable growth; accordingly, we failed to accept our hypothesis $\mathrm{H}_{2}$. Consistent with the findings of Li et al. (2015), our results also demonstrates an insignificant association between CEO's duality (DUALITY) and corporate sustainable growth, indicating that there is no linkage between CEO's duality and corporate sustainable growth; to such a degree, we failed to accept our hypothesis $\mathrm{H}_{3}$. Likewise, the result for the Board's Education (B-EDU), also exhibits no notable relationship with corporate sustainable growth; consequently, we reject our hypothesis $H_{4}$. Surprisingly, the result for Board Independence (B-IND), exhibits a significant negative association with corporate sustainable growth, indicating that higher board independence (i.e., higher proportion of independent directors on the board) may adversely affect a firm's potentiality to attain sustainable growth. This result is in line with the stewardship theory and researches by Arora \& Sharma (2016), Vrenken (2014), Arosa et al. (2013), Bhagat \& Bolton (2008), Dalton et al. (1998) yet contradicts our hypothesis $H_{5}$ and the research by Li et al. (2015) that noted a significant positive association between board independence and corporate sustainable growth. The logical reasoning behind this phenomenon is that higher board independence tends to decelerate the board's functioning and efficiency produced as a result of frequent interference; consequently, a firm squanders its potential opportunities. In contrast, Presence of Family Affiliation on the Board (P-FAMA) is found to demonstrate a significant positive association with the corporate sustainable growth. It implies that the firms having a higher presence of family affiliation on the board are more competent to attain sustainable growth. This result also supports the stewardship theory and researches by Che and Langli (2015) however contradicts our hypothesis $H_{6}$. The logical reasoning behind this phenomenon is that family affiliated director's treat the firm as if it is their own child, and takes, decisions judiciously. In addition, it is likely that communication is more efficient when more family affiliated directors are present on the board instead of outsiders (Che and Langli, 2015; Jaskiewicz \& Klein, 2007).

Regarding the control variable, the study has failed to observe any significant association of leverage (LEV) with corporate sustainable growth.

In sum, the findings of Model 1 suggest that the Board Size (BS), Boards Independence (B-IND),

Tabel 6. Random-effect GLS Regression Results (for Model 1)

\begin{tabular}{cccc}
\hline CSG & Coef. & Std. Err. & $\mathrm{z}$ \\
\hline CONS_ & -0.253 & 0.197 & -1.290 \\
BS & $0.179^{* *}$ & 0.081 & 2.220 \\
P-WOM & 0.353 & 0.289 & 1.220 \\
DUALITY & -0.090 & 0.053 & -1.710 \\
B-EDU & 0.010 & 0.070 & 0.150 \\
B-IND & $-0.215^{* *}$ & 0.102 & -2.100 \\
P-FAMA & $0.097^{* *}$ & 0.051 & 1.890 \\
LEV & -0.006 & 0.007 & -0.950 \\
$\mathrm{R}^{2}$ & 0.027 & & \\
WALD CHI2 & $16.56^{* *}$ & & \\
$\mathrm{~N}$ & 695 & & \\
\hline
\end{tabular}

Source: Author's own tabulation using STATA software

Notes: $\mathrm{p}<0.05^{* *}, \mathrm{p}<0.01^{*}$ 
and the Presence of Family Affiliation on the Board (FAM-A) exercise profound influence in explaining the Corporate Sustainable Growth in India.

Table 7 presents the regression results for Model 2 (i.e., of robustness check). Using Pooled OLS regression model (as suggested by the Breusch and Pagan Lagrangian multiplier test for random effects), the results for robustness test suggest that board size (BS) demonstrates a significant negative association with the dependent variable - Deviation (DEV), which indicates that the firms having a larger board size tends to reduce the deviation, and turn out to be more competent to attain sustainable growth. This result is consistent with the basic result as obtained. The result for Board Independence (B-IND), exhibits a significant positive association with the dependent variable - Deviation (DEV), indicating that higher board independence (i.e., a higher proportion of independent directors on the board) is likely to enlarge the deviation and reduce the firms' capability to attain sustainable growth. This result as well in line with the basic result, as obtained. However, the result for the Presence of Family Affiliation on the Board (FAM-A) failed to exhibit any notable association with Deviation (DEV). This contradicts the basic result where a significant linkage between the Presence of Family Affiliation on the Board (FAM-A) and corporate sustainable growth was obtained. As regards other explanatory variables, the result of the robustness test is consistent with the basic results.

Thus, the results for Model 2 (i.e., of the robustness test) offers evidence that almost all the findings of this study are robust.

\section{MANAGERIAL IMPLICATIONS}

This study contributes constructively to the extant literature on corporate governance and corporate sustainable growth by revealing the profound impact of corporate governance practices on corporate sustainable growth in India. The above shreds of empirical evidence exhibit the most suitable board size in order to attain corporate sustainable growth. Besides, the findings show the adversity of the excessive board independence on the attainment to corporate sustainable growth. Thus, this study would be valuable for the Indian Government and other policymakers too, in

Tabel 7. Pooled OLS Regression Results (for Model 2)

\begin{tabular}{cccc}
\hline DEV & Coef. & Std. Err. & $\mathrm{t}$ \\
\hline CONS_ & 2.236 & 0.914 & 2.450 \\
BS & $-1.085^{* *}$ & 0.375 & -2.890 \\
P-WOM & -2.249 & 1.397 & -1.610 \\
DUALITY & 0.041 & 0.244 & 0.170 \\
B-EDU & 0.181 & 0.326 & 0.550 \\
B-IND & $1.057^{* *}$ & 0.483 & 2.190 \\
P-FAMA & -0.239 & 0.234 & -1.020 \\
LEV & 0.029 & 0.322 & 0.910 \\
$R^{2}$ & 0.027 & & \\
Adj. $R^{2}$ & 0.017 & & \\
F & $2.72^{*}$ & & \\
$\mathrm{~N}$ & 695 & & \\
\hline
\end{tabular}

Source: Author's own tabulation using STATA software

Notes: $\mathrm{p}<0.05^{* *}, \mathrm{p}<0.01^{*}$ 
framing effective governance policies for the Indian companies in light of corporate sustainable growth. Additionally, in today's vibrant and competitive business world, managing corporate growth is undoubtedly a big confrontation for corporate managers. As demonstrated, this study provides corporate managers with a mantra that if good governance practices are employed, the firm's growth and its policies can be managed effectively for future benefits.

\section{CONCLUSION}

The present study aimed to investigate the impact of corporate governance practices on corporate sustainable growth in India. The ultimate findings of this study bring to light that out of the selected corporate governance measures, Board Size (BS) and the Board Independence (B-IND) exercise a profound influence in explaining the Corporate Sustainable Growth (CSG). However, no significant linkage could be established between the other selected explanatory variables viz. CEO's Duality (DUALITY), Proportion of Women Directors on Board (P-WOM), Boards Education (B-EDU), Presence of Family Affiliation on the Board
(P-FAMA) and Corporate Sustainable Growth (CSG).

The research findings offer evidence that in the Indian context, larger boards (i.e., a larger board size) and lesser board independence (i.e., a limited proportion of independent directors on the board) are the key contributors to the corporate sustainable growth. In sum, it can be asserted that good corporate governance practice not only brings in superior management and business performance but also, enables a firm to attain affordable heights.

This study presents ample scope of future research for the academicians, economists, corporate managers, and scholars as well. The present study can be further extended by taking into consideration the other corporate governance determinants like Audit Committee, Remuneration Committee, Board Meetings, and others or by expanding the sample size, the period of the study, and the control variables. Additionally, further studies can be carried out to explore the effect of Board Gender Diversity or Boards Ownership Structure on Corporate Sustainable Growth.

REFEREN CES

Adams, R. B., \& Ferreira, D. (2009).Women in the Boardroom and Their Impact on Governance and Performance. Journal of Financial Economics, 94(2), 291309.

Ahren, K.R. \& Dittmar, A. (2012). The Changing of the Boards: The Impact on Firm Valuation of Mandated Female Board Representation. The Quarterly Journal of Economics, 127,137- 197.

Akpan, E.O. \& Amran, N.A. (2014). Board characteristics and company performance: Evidence from Nigeria. Journal of Finance and Accounting, 2(3), 81-89. doi: 10.11648/j.jfa.20140203.17

Ali, M. (2016). Impact of Corporate Governance on Firm's Financial Performance (A Comparative Study of Developed and Non Developed Markets). Arabian Journal of Business and Management Review, 6(6), 1-6. DOI: 10.4172/2223-5833.1000272

Amer, M. M. (2016). Measuring the effect of the Board of Directors and Audit Committee Characteristics on Firm Financial Performance in Egypt. (Ph.D Dissertation), Cardiff Metropolitan University.

Amouzesh, N., Moeinfar, Z., \& Mousavi, Z. (2011). Sustainable Growth Rate and Firm Performance: Evidence From Iran Stock Exchange. International Journal of Business and Social Science, 2(23) [Special Issue - December], 249-255. Retrieved from http://www.ijbssnet.com/journals/Vol_2_No_23_Special_Issue_December_2011/30.pdf 
Appiadjei, E.A., Ampong, G.O., \& Nsiah, F. (2017), Board, Gender Diversity and Firm Performance. International Journal of Economics, Commerce and Management, 5(10), 1-16.

Anderson, R. C., and Reeb, D. M. (2003). Founding-Family Ownership and Firm Performance: Evidence from the S\&P 500. The Journal of Finance, 58(3), 1301-1328.

Arora, A., and Sharma, C. (2016). Corporate Governance and Firm Performance in Developing Countries: Evidence from India, Corporate Governance, 16 (2), 420-436. https://doi.org/10.1108/CG-01-2016-0018

Arosa, B., Iturralde, T., \& Maseda, A. (2013). The board structure and firm performance in SMEs: Evidence from Spain. Investigaciones Europeas de Dirección y Economía de la Empresa, 19, 127-135.

Ataünal, L., Gürbüz, A. O., \& Aybars, A. (2016). Does High Growth Create Value for Shareholders? Evidence from S\&P500 Firms. European Financial and Accounting Journal, 11(3), 25-38.

Azeez, A.A. (2015). Corporate Governance and Firm Performance: Evidence from Sri Lanka. Journal of Finance and Bank Management, 3(1), 180-189. DOI: 10.15640/jfbm.v3n1a16

Bates, C. (2013). Governance in SMEs: Moving beyond red tape. http://entreprenuer.co.za

Bathula, H. (2008). Board characteristics and firm performance: Evidence from New Zealand, (Ph.D Dissertation), Auckland University of Technology.

Bebchuk, L. A., \& Weisbach, M. S. (2010). The State of Corporate Governance Research. The Review of Financial Studies, 23(3), 939-961. https://doi.org/10.1093/rfs/hhp121.

Berardino, D. (2016). Corporate Governance and Firm Performance in New Technology Ventures. Procedia Economics and Finance, 39, 412-421.

Bhagat, S., and Bolton, B. (2008). Corporate Governance and Firm Performance. Journal of Corporate Finance, 14, 257-273.

Blair, M. (1995). Ownership and control: rethinking corporate governance for the twenty-first century, Brookings Institution, Washington DC.

Byrd, J.W. \& Hickman, K.A. (1992). Do outside directors monitor managers: evidence form tender offer birds. Journal of Financial Economics, 32(2), 195-221.

Burkart, M., Pannunzi, F., \& Schleifer, A. (2003). Family firms. The Journal of Finance, 58, 2167-2202.

Cabrera-Suárez, M. K., \& Martín-Santana, J. D. (2015). Board composition and performance in Spanish non-listed family firms: The influence of type of directors and CEO duality. Business Research Quaterly, 18(4), 213-229. https://doi.org/10.1016/j. brq.2014.08.001

Campbell, K., \& Mínguez-Vera, A. (2008). Gender diversity in the boardroom and firm financial performance. Journal of business ethics, 83(3), 435-451.

Canh, L.Q., Kim, K.S., \& Yi, Y. (2014). Effects of Corporate Governance on the Performance of Private Economic Groups in Vietnam. Journal of International Trade \& Commerce, 10(6), 39-56.

Carter, D.A., Simkins, B.J. \& Simpson, W.G. (2003), "Corporate Governance, Board Diversity, and Firm Value”, Financial Review, 38(1), 33-53.

Che, L., and Langli, J. C. (2015). Governance Structure and Firm Performance in Private Family Firms. Journal of Business Finance \& Accounting. http://dx.doi.org/10.2139/ssrn.2435869

Chen, T. (2015), "Institutions, board structure, and corporate performance: Evidence from Chinese firms", Journal of Corporate Finance, Vol. 32.

Christiansen, L., Lin, H., Pereira, J., Topalova, P., \& Turk, R. (2016), Gender Diversity in Senior Positions and Firm Performance: Evidence from Europe, (IMF Working Paper), European Department, 1-29.

Coles, J.L., Daniel, N.D. and Naveen, L. (2008). Boards: Does one size fit all? Journal of Financial Economics, 87, 329-356. https://doi.org/10.1016/j.jfineco.2006.08.008

Daily, C., Dalton, D., and Cannella, A. (2003). Corporate Governance: Decades of Dialogue and Data. Academy of Management Review, 28, 371-382.

Dalton, D.R., Daily, C. M., Ellstrand, A. E., and Johnson. J. L. (1998). Meta-analytic Reviews of Board Composition, Leadership Structure, and Financial Performance. Strategic Management Journal, 19, 269-290.

Daunfeldt, S. O., \& Rudholm, N. (2012). Does gender diversity in the boardroom improve firm performance?, (HUI working papers no. 60), HUI Research.

De Andrés, P., Azofra, V., \& Lopez-Iturriaga, F. (2005). Corporate Boards in OECD Countries: Size, Composition, Functioning and Effectiveness. Corporate Governance An International Review, 13(2), 197-210. doi: 10.1111/j.1467-8683.2005.00418.x

Donaldson, L., and Davis, J. H. (1991). Stewardship theory or agency theory: CEO governance and shareholder returns. Australian Journal of Management. 16, 49-64.

Eisenberg, T., Sundgren, S., \& Wells, M.T. (1998). Larger board size and decreasing firm value in small firms. Journal of Financial Economics, 48, 35-54. 
Eisenhardt, K.M. (1989). Agency theory - An Assessment and Review. Academy of Management Review, 14, 57-74.

Ehikioya, B.I. (2009). Corporate governance structure and firm performance in developing economies: evidence from Nigeria. Corporate Governance: The International Journal of Business in Society, 9(3), 231-243.

Erhardt, N.L., Werbel, J.D., \& Shrader, C.B. (2003), Board of Director Diversity and Firm Financial Performance, Corporate Governance: An International Review, 11(2), 102-111.

Fama, E. F. (1980). Agency problems and theory of the firm. Journal Political Economics, 88(2), 288 - 307.

Fama, E. F., \& Jensen, M. C. (1983). Separation of ownership and control. Journal of Law and Economics, 26, 301-325.

Fan, P.S. (2012), Is board diversity important for firm performance and board independence? An exploratory study of Singapore listed companies, (MAS Staff Paper No. 52), The Monetary Authority of Singapore (MAS).

Fauzi, F. \& Locke, S. (2012). Board Structure, Ownership Structure and Firm Performance: A Study of New Zealand ListedFirms. Asian Academy of Management Journal of Accounting of Finance, 8(2), 43-67.

Firer, C. (1995). Investment Basics: XXXI. Sustainable Growth Models. Investment Analyst Journal, 24(41), 57-58. Retrieved from https://www.tandfonline.com/doi/abs/10.1080/10293523.1995.11082349

Fonseka, M.M., Ramos, C.G., \& Tian, G. (2012). The Most Appropriate Sustainable Growth Rate Model for Managers and Researchers. The Journal of Applied Business Research, 28(3), 481-500.

Forbes, D.P., \& Milliken, F. (1999). Cognition and corporate governance: Under-standing board of directors as strategic decision: Making groups. Academy ofManagement Review, 3, 489-505.

Freeman, R. E. 1984. Strategic management: A stakeholder approach. Pitman, Boston, MA.

Gill, A. \& Mathur, N. (2011). Board Size, CEO Duality, and the Value of Canadian Manufacturing Firms. Journal of Applied Finance and Banking, 1(3), 1-13.

Guest, P. (2009). The impact of board size on firm performance: evidence from the UK. European Journal of Finance, 15(4), 385-404.

Hambrick, D. C., \& Mason, P. A. (1984). Upper Echelons: The organizations as a reflection of its top managers. Academy of Management Review, 9(2), 193 - 206.

Hermalin, B. \& Weisbach, M. (2003). Boards of directors as an endogenously determined institution: a survey of the economic literature. Federal Reserve Bank of New York Policy Review, 9(1), 7-26.

Heravia, S., Saat, N. M., Karbhari, Y., \& Nassir, A. (2011). Effective Oversight Roles of Board of Directors: The case of listed firms on Bursa Malaysia. World Review of Business Research, 1(1), 231 - 245.

Hernandez, M. (2007). Promoting Stewardship Behavior in Organizations: A Leadership Model. Journal of Business Ethics, 80,121-128.

Herdjiono. I., and Sari, I. M. (2017). The Effect of Corporate Governance on the Performance of a Company. Some Empirical Findings from Indonesia. Journal of Management and Business Administration, 25(1), 33-52.

Higgins, Robert C. (1977). How Much Growth Can a Firm Afford? Financial Management, 6(3), 7-16.

Higgins, Robert C. (2017). Analysis for Financial Management. India: McGraw-Hill Education (India) Private Limited.

Jackling, B. \& Johl, S. (2009). Board structure and firm performance: Evidence from India's top companies. Corporate Governance: An International Review, 17(4), 492-509

Jaskiewicz, P., \& Klein. S. (2007). The impact of goal alignment on board composition and board size in family businesses. Journal of Business Research, 60, 1080-1089.

Jensen, M. (1993). The Modern Industrial Revolution, Exit, and the Failure of Internal Control Systems. The Journal of Finance, 48(3), 831-880, https://doi.org/10.1111/j.1540-6261.1993.tb04022.x

Jensen, M.C. \& Meckling, W.H. (1976). Theory of the firm: managerial behavior, agency costs, Journal of Financial Economics, 3(4), 305-360. https://doi.org/10.1016/0304-405X(76)90026-X

Jensen, M. C. (2012). The modern industrial revolution, exit, and the failure of internal control systems. The Journal of Finance, 48(3), 831-880.

Johl, S. K., Kaur, S., \& Cooper, B. J. (2015), Board characteristics and firm performance: Evidence from Malaysian public listed firms. Journal of Economics, Business and Management, 3(2), 239-243.

Kalsie, A., \& Shrivastav, S. M. (2016). Analysis of Board Size and FirmPerformance: Evidence from NSE Companies Using Panel Data Approach, Indian Journal of Corporate Governance, 9(2). https://doi.org/10.1177/0974686216666456

Kamardin, H., \& Haron H. (2011). Roles of Board of Directors: Monitoring and resource dependency perspectives from Malaysia. International Journal of Economics and Accounting, 2(3), 282 - 306.

Keay, A. (2017). Stewardship Theory: Is Board Accountability Necessary?, International Journal of Law and Management, 59 (6), 1292-1314.

Kiel, G. C. \& G. J. Nicholson (2003a). Board composition and corporate performance: how the Australian experience informs contrasting theories of corporate governance. Corporate Governance, 11(3), 189-205. 
Khan, A., \& Awan, S.H. (2012). Effect of board composition on firm's performance: A case of Pakistani listed companies. Interdisciplinary Journal of Contemporary Research in Business, 3(10), 853-863.

Klepczarek, E. (2017). Corporate Governance Theories in the New Institutional Economics Perspective: The Classification of Theoretical Concepts. Studia Prawno-Ekonomiczne, t.CV, 243-257. DOI: 10.26485/SPE/2017/105/14

Kluvers, R. and Tippett, J. (2011). An exploration of stewardship theory in a Not-for Profit organisation. Accounting Forum, 35, 275-284. DOI: 10.1016/j.accfor.2011.04.002

Lansberg, I., Perrow, C., \& Rogolsky, S. (1988). Family business as an emerging field. Family Business Review, 1, 1-8.

Lee-Kuen, I.Y., Sok-Gee, C., \& Zainudin, R. (2017), Gender Diversity and Firms' Financial Performance in Malaysia. Asian Academy of Management Journal of Accounting and Finance, 13(1), 41-62.

Li, X., Liu, Z., \& Ren, F. (2015). Study on Relationship between Board Characteristics and Sustainable Growth of Family Listed Companies. Science Journal of Business and Management, 3(1), 11-16. doi: 10.11648/j.sjbm.20150301.12

Liang, N. \& Li, J. (1999). Board structure and firm performance: New evidence from China'sprivate firms. China Centre for Economic Research. Retrieved from http://www.ccer.edu.cn/workingpaper/paper/e1999008.pdf

Lipton, M., \& Lorsch, J. (1992). A modest proposal for improved corporate governance. Business Lawyer, 48, 59-77.

Liu, Y., M.K. Miletkov, Z. Wei \& T. Yang (2015), Board independence and firm performance in China. Journal of Corporate Finance, Vol. 30.

Ljungquist, U. (2007). Core competency beyond identification: presentation of a model. Management Decision, 45(3), 393-402.

Madison, K. J. (2014). Agency Theory and Stewardship Theory Integrated, Expanded, and Bounded by Context: An Empirical Investigation of Structure, Behavior, and Performance within Family Firms. (Ph.d Dissertation), The University of Tennessee, Knoxville.

Mahadeo, J.D., Soobaroyen, T. \& Hanuman, V.O. (2012). Board Composition and Financial Performance: Uncovering the Effects of Diversity in an Emerging Economy. Journal of Business Ethics, 105(3), 375-388.

Mashayekhi, B. \& Bazaz, M.S. (2008). Corporate governance and firm performance in Iran. Journal of Contemporary Accounting \& Economics, 4 (2), 156-172.

Mukherjee, T., \& Sen, S.S. (2018). Corporate Social Responsibility and Sustainable Growth: An Evidence from India. International Journal of Business Insights \& Transformation, 11(2), 70-79.

Nazar, M.C.A. \& Rahim, R.A. (2015). Impact of Corporate Board Size on Corporate Performance: Evidence from Sri Lanka. International Journal of Management and Applied Science, 1(9), 40-44.

Nielsen, S., \& Huse, M. (2010). The Contribution of Women on Board of Directors: Goes Beyond the Surface. Corporate Governance: An International Review. 18(2), 136-148.

Oludele, O. I., Magret A. O., \& Tobiah, O. (2016). Impact of Board size on the Financial Performance of the Listed Manufacturing Companies in Nigeria. Journal of Business and Management, 18(11), 76-83.

Orozco, L. A., Vargas, J., \& Galindo-Dorado, R. (2018). Trends on the Relationship between Board Size and Financial and Reputational Corporate Performance: The Colombian Case. European Journal of Management and Business Economics, 27(2), 183-197. http://doi.org/10.1108/EJMBE-02-2018-0029

Pandey, I. M. (2015). Financial Management. India: Vikas Publishing House Pvt. Ltd.

Pandit, N., \& Tejani, R. (2011). Sustainable Growth Rate of Textile and Apparel Segment of the Indian Retail Sector. Global Journal of Management and Business Research, 11(6), 39-44. Retrieved from https://journalofbusiness.org/index.php/ GJMBR/article/download/515/458

Pass, C. L. (2004). Corporate Governance and the Role of Non-executive Directors in Large UK Companies: An Empirical Study. Corporate Governance International Journal of Business in Society, 4(2), 52-63. DOI: 10.1108/14720700410534976

Pearce, J. A., \& Zahra, S. A. (1992). Board Composition from a Strategic Contingency Perspective. Journal of Management Studies, 29(4), 411-438.

Pérez-González, F. (2006). Inherited control and firm performance. Am. Econ. Rev., 96, 1550-1588.

Pfeffer, J. \& Salancik, G. (1978). The External Control of Organizations: A Resource Dependence Perspective. New York: Harper and Row.

Pintea, M. O., \& Fulop, M. T. (2014). Corporate Governance and Performance in the Context of Sustainable Development. SEA - Practical Application of Science, 2(3), 519-526.

Ramezani, C., Soenen, L. A., \& Jung, A. (2001). Growth, Corporate Profitability, and Value Creation. Financial Analysts Journal, 58(6). https://doi.org/10.2139/ssrn.304880

Ross, S. A. (1973). The Economic Theory of Agency: The Principal's Problem. The American Economic Review, 63(2). $134-139$.

Ross, S.A., Westerfield, R.W., \& Jordan, B.D. (2012). Fundamentals of Corporate Finance. India: McGraw-Hill Education (India) Private Limited.

Rouf, A. (2012). The Relationship between Corporate Governance and Value of the Firm in Developing Countries: Evidence from Bangladesh. Journal of Economics and Business Research, 18(1), 73-85. 
Rutherford, M. W., Muse, L. A., \& Oswald, S. L. (2006). A New Perspective on the Developmental Model for Family Business. Family Business Review, 19(4), https://doi.org/10.1111/j.1741-6248.2006.00079.x

Sakai, H., \& Asaoka, H. (2003). The Japanese Corporate Governance System and Firm Performance: Toward Sustainable Growth. ESRI International Forum Paper.

Sánchez, M.S. (2017), Women on Corporate Boards and Firm Performance: Evidence from Spain, (Working Paper), Universitat Autonoma de Barcelona, 1-53.

Sarens, G. \& Merendino, A. (2016). Multiple Agency Theory in Corporate Governance: An Alternative Lens to study Independent Directors. Working Paper Series, Louvain School of Management Research Institute.

Schulze, W., Lubatkin, M., Dino, R., \& Buchholtz, A. (2001). Agency relationships in family firms: Theory and evidence. Organization Science, 12, 99-116.

Shleifer, A. \& Vishny, R.W. (1997). A survey of corporate governance. Journal of Finance, 52(2), 727-783. https://doi. org/10.1111/j.1540-6261.1997.tb04820.x

Singh, M. \& Davidson, W.N. (2003). Agency cost, ownership structure and corporate governance mechanisms. Journal of Banking and Finance, 27(5), 793-816.

Sarpong-Danquah, B., Gyimah, P., Afriyie, R.O., \& Asiamah, A. (2018). Corporate Governance and Firm Performance: An Empirical Analysis of Manufacturing Listed Firms in Ghana. Accounting and Finance Research, 7(3), 111-118. doi:10.5430/ afr.v7n3p111

Srinidhi, B., Gul, F. A., \& Tsui, J. (2011), Female directors and earnings quality, Contemporary Accounting Research, 28 (5), 1610-1644.

Ujunwa, A., Nwakoby, I., \& Ugbam, C.O. (2012), Corporate Board Diversity and Firm Performance: Evidence from Nigeria, Corporate Ownership \& Control, 9(2), 216-226.

Vafeas, N. (1999). Board meeting frequency and firm performance. Journal of Financial Economics, 53, $113-142$.

Van Horne, J.C., \& Wachowicz, J.M. (2015). Fundamentals of Financial Management. India: PHI Learning Private Limited.

Villalonga, B., \& Amit, R. (2006). How do family ownership, control and management affect firm value? Journal of Financial Economics, 80, 385-417.

Vrenken, E. (2014). Impact of Board Independence during the Crisis Period, (4th IBA Bachelor Thesis Conference), Enschede, The Netherlands.

Wanjiru, M.M. (2013). The Effect of Corporate Governance on Financial Performance of Companies Listed at Nairobi Security Exchange. MSc in Finance Project, University of Nairobi.

Wesley, C. L. (2010). The Impact of Stewardship on Firm Performance: A Family Ownership and Internal Governance Perspective. (Ph.D Dissertation), Graduate Studies of Texas A\&M University.

Wheeler, D. \& M. Sillanpaa (1997). The Stakeholder Corporation: A Blueprint for Maximizing Stakeholder Value. London, Pitman Publishing.

Yermack, D. (1996). Higher Market Valuation of Companies with a Small Board of Directors. Journal of Financial Economics, 40(2), 185-211, https://doi.org/10.1016/0304-405X(95)00844-5

Yaseer, Q. R. (2012). Affects of Female Directors on Firms Performance in Pakistan. Modern Economy, 3, 817-825. http:// dx.doi.org/10.4236/me.2012.37104

Yusoff, W. F. W, \& Alhaji, I. A. (2012). Insight of Corporate Governance Theories. Journal of Business and Management, 1, 5263. 10.12735/jbm.v1i1p52.

Zabrie, S.M., Ahmad, K., \& Wah, K.K. (2016). Corporate Governance Practices and Firm Performance: Evidence from Top 100 Public Listed Companies in Malaysia. Procedia Economics and Finance, 35, 287-296. https://doi.org/10.1016/S22125671(16)00036-8 